\title{
Challenges for Transforming Family Planning Rights into Practices in Nepal
}

\begin{abstract}
Shrestha KB ${ }^{1}$
Abstract

Transforming family planning rights into practices is not an easy task especially in a developing nation like Nepal where society is patriarchal and literacy is low. Besides, coverage and quality of reproductive health services and active involvement of the community is crucial in the transformation. For properly addressing these challenges, all the sectors that provide family planning services need to act on advocacy, creating demand, reshaping service delivery, sustainability (financial and self-reliance) and high level political and financial commitments are necessary.
\end{abstract}

\section{Keywords: family planning policy; family planning services; Nepal.}

\section{Introduction}

The number of children ever born affects the socioeconomic condition of the people in a country. Empirical studies especially in developing countries like Nepal have shown that number of children ever born (or parity) affects the socio-economic condition of the people in the country. Family size and poverty are positively associated. (1) The maternal health and family planning are closely interrelated, and they together have an impact on the quality of life. But, traditionally Nepalese society has favored high fertility in which children are considered a symbol of well-being, both socially and economically. This is evident from the popular saying which goes "may your progeny fill the hills and mountains". (2) Early marriage is common and universal in Nepal. The NDHS 2011 report showed that marriage occurs relatively early which presented that among women age 25-49, 55 percent were married by age 18 , and 74 percent were married by age 20 . The median age at first marriage among women age 25-49 is 17.5 years. The proportion of women married by age 15 declines from 24 percent among those age 45-49 to 5 percent among those age 15-19 indicating clear evidence of a rising age at first marriage. (3)

It is a disgrace for a couple, particularly the wife not to have children. High fertility is desired because by producing children, preferably sons, a woman raises her status in the family. Similarly another bitter reality of Nepalese society is that women are not frequently in a position to decide, when and with whom to become pregnant, nor can they determine the number, spacing and timing of their children. (4)

One of the central challenges posed by recent international agreements and women's advocacy movements is the application of human rights principles to reproductive health programs. Considering the women's right perspectives, the UNFPA fact sheet about safe motherhoodstated that women are often not in a position to decide when and with whom to become pregnant or to determine the number, spacing and timing of their children. Early marriages, too many childbirths, violence against women all signal the violation of woman's right to make decision about her own body.In many countries with similar level of economic development, maternal mortality was found inversely proportional to women's status. The maternal death is found higher in poorer economic strata. This showed that there was greater violation of women's right. (5)

WHO states that "family planning is a way of thinking and planning that is adopted voluntarily, on the basis of knowledge, attitude and responsible decisions by individuals and couples, in order to promote health and welfare of the family, and contribute effectively to the social development of a country. Family planning helps to avoid unwanted birth, to bring about wanted births, to regulate the intervals between pregnancies and to determine the number of children in the family". (6)

Family planning has been established as a basic human right by different conferences. The UN conference on human right held at Tehran in 1968 recognized FP as a basic human right. The Bucharest Conference held in 1974 endorsed the same view and stated that "all couples and individuals have the basic human right to decide freely and, responsibly the number and spacing of their children...." The world conference of the International Women's Year 1975 also declared "the right of women to decide freely and responsibly on the number and spacing of their children and have access to the information and means to enable them exercise that right. (7) The ICPD Cairo 1994 placed family planning within a broader context of wom-

\section{Correspondence:}

${ }^{1}$ Khadga Bahadur Shrestha

Department of Community Medicine and

Public Health

Maharajgunj Medical Campus

Institute of Medicine

Maharajgunj, Kathmandu, Nepal.

Email: khadgab@gmail.com 
en's reproductive health and rights.

Family planning and health have a two-way relationship i.e. FP affects health situation and health situation also affects family planning. Pregnancy can mean serious problems for many women which may damage the mother's health or even endanger her life. The risk of mother dying as a result of pregnancy is 10-20 times higher in developing countries as compared to the developed countries. (6) Intervening through FP strategies in the reproductive cycle of women helps to control the number, interval and timing of pregnancies and improve health. The health impacts of FP occurs primarily through (i) the avoidance of unwanted pregnancies; (ii) limiting the number of birth and proper spacing, and (iii) timing the birth, particularly first and last in relation to the age of mother. Similarly, an unwanted pregnancy may lead to an induced abortion and abortion outside the medical setting is one of the most dangerous consequences of unwanted pregnancy. So, essential aim of FP is to prevent the unwanted pregnancies. Further, repeated pregnancies increase the risk of maternal mortality and morbidity. The risk rises with each pregnancy beyond the third, and increases significantly with each pregnancy beyond the fifth. (6) Anaemia is a common problem in mothers with many children and the incidence of rupture of the uterus increases with high parity. FP is the only way to limit the size and control the interval between births.

\section{Situational Status}

At the beginning of the Christian era, nearly 2000 years ago, world population was estimated to be around 250 million. The first billion reached around 1800, second billion came in 130 years (around 1930), the third billion in 30 years (around 1960), the fourth billion in 15 years (around 1974), the fifth billion in 12 years (around 1987), and the sixth billion in 12 years (in 2000). It is expected to reach 8 billion by 2025 and 9 billion by 2050. (6)

In almost all developing countries, the number of women of reproductive age (age 15 to 49) will grow between 2005 and 2015 because of the large number of young people in these countries and the demand for contraceptives is projected to grow due to couples' desires for smaller families. (8)

Globally, around 200 million women want to delay or avoid pregnancy but are not using effective contraception. This has resulted in thousands of unintended pregnancies, ill health and maternal deaths. According to the UNFPA, contraception can prevent 2.7 million infant deaths per year; reduce poverty, slow population growth and ease the pressure on the environment. (9) Being able to plan how many children to have and when to have them is a recognized human right, but, this right is not yet realized, especially among the poor.UNFPA stated that universal access to family planning could save the lives of about 175,000 women each year. Every minute, somewhere in the world, a woman dies during pregnancy or childbirth, and 20 more suffer disability. (10) en dramatically over the past four decades, from about 10 percent of women using contraception in 1965 to about 60 percent in2000. In Asia and Latin America, contraceptive prevalence is now at 71 percent and 64 percent, respectively, indicating that much of the demand for contraception has been met. Contraceptive prevalence has grown more slowly in Africa, where use of any method is 27 percent and most couples use family planning to space rather than limit births. The global regional averages conceal wide variation between and within countries. For example, contraceptive prevalence in Latin America and the Caribbean ranges from a low of 28 percent in Haiti to a high of 77 percent in Brazil and Colombia. In Ethiopia and Nigeria (the latter is the world's ninth most populated country); use of any contraceptive method is 8 percent and 15 percent, respectively. Within countries, contraceptive prevalence may be several times higher in urban than rural areas and it also tends to be lower among the poor than the better-off. (11) Female sterilization is the most common contraceptive method, used by one-fifth of married women worldwide, but, in contrast, male sterilization is far less common in most of the countries. (12) (Table 1)

From the Table 1, we can compare the situation of health and need of family planning in Nepal with otherneighbouring countries. For the improvement of this situation, Government of Nepal implemented family planning services as essential health care component and set target in different plan documents which is shown in Table 2 .

\section{FP Activities in Nepal}

The first consciousness about family planning in Nepal started with involvement of Nepal Medical Association (NMA) in 1959. Family Planning Association of Nepal (FPAN) was formed with active involvement of NMA and supported by IPPF. Technical assistance for FP activities started with support of USAID from 1966. In 1968, FP and $\mathrm{MCH}$ project with 4 regional offices was established. National Planning Commission (NPC) set up a task force in 1974 to develop population policy for the fifth five year plan(1975-80). First fertility survey was conducted in 1976. The National Population Strategy, 1983 developed during 6th plan period is considered a milestone in the development of population policy in Nepal. From 1988, more stress was laid on the temporary methods to prevent early pregnancies and better spacing. In an effort to popularize FP in Nepal, the Nepal Contraceptive Retail Sales (CRS) company was established in 1978. In 1995, a separate ministry of "population and environment" was created to enable effective implementation of activities to control the population explosion. (7)

\section{Challenges for transforming FP Right Education}

Education, particularly women's education, plays an important role in greater economic security, better health, and overall social progress. For many families, the value of education is not recognized. It is often difficult for people to see a direct connection between the educational level of a household and social benefits. (16) 
Table 1: Comparison of some Indicators of Nepal with its neighbour countries(13) (14)

\begin{tabular}{lccccc}
\hline Health Indicators & Nepal & India & Bangladesh & Pakistan & Sri Lanka \\
\hline Life Expectancy & 68.0 & 64.8 & 68.3 & 65.0 & 74.6 \\
\hline IMR per 1,000 Live Births & 41.0 & 48.0 & 38.0 & 70.0 & 14.0 \\
\hline Maternal Mortality Ratio & 170.0 & 200.0 & 240.0 & 260.0 & 35.0 \\
\hline Women 15-49 (\%) & 49.9 & 52.1 & 52.6 & 50.1 & 55.1 \\
\hline TFR per Woman 15-49 & 3.1 & 2.7 & 3.0 & 3.1 & 1.9 \\
\hline Contraceptive Prevalence Rate (Any method) & 50.0 & 55.0 & 56.0 & 27.0 & 68.0 \\
\hline Unmet Need for FP, Total (\%) & 25.0 & 21.0 & 17.0 & 25.0 & 7.0 \\
\hline Deliveries Attended by Skilled Attendant & 36 & 58 & 27 & 45 & 99 \\
\hline
\end{tabular}

Table 2: National targets in plan documents of Nepal (15)

\begin{tabular}{lcccc}
\hline Health Indicators & $\begin{array}{c}\text { Situation at the } \\
\text { end of 9th Plan }\end{array}$ & $\begin{array}{c}\text { Target of } \\
\text { 10th Plan }\end{array}$ & $\begin{array}{c}\text { Target of 3 year } \\
\text { Interim Plan }\end{array}$ & $\begin{array}{c}\text { Targets of Second Long } \\
\text { Term Health Plan }\end{array}$ \\
\hline Life Expectancy & 57.6 & 62.0 & - & 68.7 \\
\hline $\begin{array}{l}\text { Total Fertility Rate } \\
\begin{array}{l}\text { Contraceptive Prevalence } \\
\text { Rate }\end{array}\end{array}$ & 4.1 & 3.5 & 3.0 & 3.05 \\
\hline $\begin{array}{l}\text { Delivery by Skilled } \\
\text { Birth Attendants }\end{array}$ & 39.0 & 50.0 & 53 & 58.2 \\
\hline $\begin{array}{l}\text { Maternal Mortality Ratio } \\
\text { (per 100000) }\end{array}$ & 439.0 & 55.0 & - & 95.0 \\
\hline
\end{tabular}

Literacy (reported ability to read and write a simple letter or their name) rate is highest among 11-15 years old at $77 \%$ in males and $56 \%$ in females. It falls steadily with increasing age, down to $29 \%$ in males and $2 \%$ in females of 61 years or older. Taking age into account, females have nearly four times the risk among males of being illiterate. Literacy is higher in urban areas and varies considerably between different areas of Nepal. (17) Nepal Demographic and Health Survey 2011 states that two-fifths of uneducated women had no exposure to family planning information in any media compared with just 1 percent of women with SLC and higher education. (3)

Not surprisingly the rural women with no education and those from the poorest households were more likely to state that accessing health care for any reason was a big problem. Education also influences media exposure positively. Hence, poor education especially of women possesses one of the greatest challenges for transforming the FP right to practice in the Nepalese society.

\section{Lack of Information}

Nepal is a country of rich cultural diversity within which the majority of communities are made up of highly stratified, ethnically mixed populations. Individual settlements are often isolated from one another due to the mountainous terrain, scarcity of roads and difficulties of travelling during the monsoon season. Most people live in traditional, patriarchal family structures within which the status of women is particularly low. Under these circumstances, communicating family planning messages to key audiences is particularly challenging. (18) In Nepal, the most common media source is the radio. Television is mostly found in urban areas, while the print media are accessed mostly by the educated.

\section{Coverage and quality of RH Services}

The health care that a woman receives during pregnancy, at the time of delivery, and soon after delivery is important for the survival and well-being of both the mother and the child. Nepal Demographic and Health Survey 2011 stated that only 58 percent of mothers received antenatal care from the trained health workers for their most recent birth but15 percent of women received no antenatal care for births in the five years before the survey. Similarly 35 percent of births take place in health facilities ( 26 percent are delivered in a public-sector health facility, 2 percent in a nongovernment facility, and 7 percent in a private facility). There we still two-thirds of births (63 percent) take place at home. Delivery in a health facility is more common among mothers less than age 34 ( 35 to 41 percent) and mothers of first-order births (54 percent). Survey also stated that just more than two-fifth (45 percent) of women received postnatal care for their last birth. (3)

The high rates of maternal mortality among poor women in Nepal are linked to low utilization of obstetric care services. Underlying determinants include widespread poverty, the low status of women, early female marriage, high parity and low family planning use and a weak health service. (19)

The major problems of seeking medical care are getting permission to go for treatment, getting money for treatment, distance to a health facility, having to take transport, not wanting to go alone, security concerns, concern that there may not be a female health provider or unavailability of health provider and concern that the FP commodity or drugs available. About one in two women expressed concern that there may not be a female health provider or the availability of health providers, that there may be lack of FP device available, and that they did not want to go alone, and expressed concerns about security. Concerns about money, transport and distance were cited by about two in five women. (20) 
The low standards of care found in many district health facilities reflect a number of underlying generic issues within the health sector including lack of resources, poor quality and badly maintained buildings, insufficient and inappropriate staffing, lack of professional support for staff and poor management. This shows that there is poor coverage and quality of reproductive health services which is another challenges for transforming FP rights.

\section{Community Participation}

Active community participation in health program is a key issue felt from long before. Maternal mortality impacts heavily on society and is thus as much a social as a health issue. Since the government does not have sufficient resources or outreach capacity to meet the scale of current needs, other stakeholders, such as local civil society organizations, need to be involved to supplement government efforts. (21) The empirical findings from the many countries showed that individuals make better choices about contraception when they participate in the family planning program activities in their villages or urban neighborhoods. Lack of community participation has become a great challenge for transforming family planning right into practice in Nepal.

\section{Ways of meeting these challenges}

To meet these challenges, all sectors that provide family planning services need to act on four fronts. First, we must advocate increasing understanding at the broader policy level of the linkages between poverty, development, and family planning. Successful advocacy will clarify the connection between family planning and broader health and development goals. Second, we must ensure that family planning services are cost effective, accessible, and of good quality near to the users. Effectively reshaping service delivery to ensure affordability, accessibility, and quality will help maximize the reach of family planning services. Third, family planning program managers need to create demand for family planning. Behavior change communication, including client education, community mobilization, and mass media, has the potential to change community norms as well as individual attitudes, thus building support for reproductive rights and overcoming social opposition to family planning. It can also increase knowledge and motivate potential clients to act. Finally, we should work to improve financial sustainability of family planning programs. Carefully analyzing costs and revenues, and changing staffing patterns (gender sensitive) and service practices accordingly, can make programs more self-reliant. Partnering with the private sectors, for example, through social marketing and social franchising can increase the availability of affordable family planning services in the community and relieve pressure on the public health system. The private sector is playing an important role in sustaining the success of family planning in Nepal. By fostering public-private partnerships (PPPs), the government can reduce its burden and help ensure FP products and services are consistently available in the long term basis. A high-level political and financial commitment is also urgently needed to promote family planning program in Nepal.

\section{Conclusion}

Transforming family planning rights into practices in national program is a great challenge in a country like Nepal with patriarchal society. The major challenges are poor educational status (particularly among women), lack of information and access to required $\mathrm{RH}$ services, coverage and quality of $\mathrm{RH}$ services (equitable access, quality of care, complications arising out of early marriage, unsafe abortion and negligence on antenatal and postnatal care) and low active community participation. For properly addressing these challenges, all sectors that provide family planning services need to act on advocacy, creating demand, reshaping service delivery and sustainability (financial and self-reliance). Similarly, a high level political and financial commitment is also necessary alongside. Considering these problems, Nepal has to design family planning services to provide a constellation of contraceptive methods/services that reduce fertility, enhance maternal and neonatal health, child survival, and contribute to bringing about a balance in population growth and socioeconomic development, resulting in an environment that will help the Nepalese people improve their quality of life.

\section{References}

1. CBS. Maternity and Family Planning. Kathmandu: Central Bureau of Statistics, 2010/11 2011.

2. Karki YB. Fertility levels, Patterns and Trends in Nepal. Kathmandu: UNFPA, 2003.

3. New Era MO. Nepal Demographic Health Survey 2011. Kathmandu: New Era, 2012.

4. DoHS/GoN. Annual Report. Kathmandu: MoHP/DoHS, 2068/69.

5. UNFPA. Facts about Safemotherhood 2013 [7 November 2013]. Available from: http://web.unfpa.org/mothers/facts.htm.

6. Park K. Park's Textbook of Preventive and Social Medicine. 20th ed. India: M/s Banarsidas Bhanot; 2009.

7. Dixit DH. Family Planning and MCH Activities. The Quest for Health (The Health Services of Nepal). Kathmandu: Educational Enterprise (P) Ltd.; 1999

8. PRB. Family Planning Worldwide 2013 data Sheet: Population Reference Bureau; 2013 [1 Dec 2013]. Available from: http://www.prb.org/ pdf13/family-planning-2013-datasheet_eng.pdf.

9. Ruhangariyo D, Mbarara. Family Planning: Reducing the unmet need 2011 [2 Dec 2013]. Available from: http://www.newvision. co.ug/D/9/34/762797.

10. UNFPA. A Global Need for Family Planning 2008 [24 Nov 2013] Available from: http://www.unfpa.org/rh/planning.htm.

11. PATH U. Meeting the Need: Strengthening Family Planning Program. Seattle: 2006.

12. nott DL. Sterilization (Female Sterilization and Vasectomy) 2012 [5 Dec 2013]. Available from: http://www.patient.co.uk/pdf/2800.pdf.

13. OECD;WHO. Health At a Glance Asia/Pacific 2012: WHO; 2012 [2 Dec 2013]. Available from: http://www.oecd.org/els/health-systems/ HealthAtAGlanceAsiaPacific2012.pdf.

14. WHO. 11 Health Questions in 11 SEAR Countries. India: 2007.

15. IPPF;FPAN. Country Situation: Introduction 2008 [4 June 2012] Available from: http://www.fpan.org/demo/intro.html. 
16. UNFPA. Empowering Women through Education: UNFPA; 2013 [14 November 2013]. Available from: http://www.unfpa.org/gender/empowerment2.htm.

17. HMG/Nepal, UNICEF. Primary Education. Nepal Multiple Indicator Surveillance. Kathmandu: HMG Nepal; UNICEF; 1996.

18. GoN D. Getting the Message Across 2004 [18 Dec 2012]. Available from: http://www.nsmp.org/getting_message_across/.

19. YR Baral KL, Jo Skinner, Edwin R van Teijlingen. Maternal health services utilization in Nepal: progress in the new millennium. Health Science Journal. 2012;6(4):618-633.

20. Jha NK. Factors Associated with First Delay to Seek Emergency Obstetric Care Services among the mother of Matsari VDC of Rautahat District. Journal of Health and Allied Science. 2012;2(1):54-56.

21. Danny Burns FH, Marilyn Taylor, Pete Wilde and Mandy Wilson. Making Community Participation Meaningful: A Handbook for Development and Assessment. UK: he Joseph Rowntree Foundation 2004 2004. 75 p. 